\title{
Pembelajaran Daring IPS Berbasis Google Classroom pada Masa Wabah Covid-19 kelas IX SMP Negeri 2 Kalimanah
}

\author{
Google Classroom-Based Online Learning on Social Sciences Subject during the Covid-19 \\ pandemic on the Ninth Grade of SMP Negeri 2 Kalimanah
}

\author{
Nur Said Manfaluti \\ SMP Negeeri 2 Kalimanah Purbalingga
}

\section{ARTICLE INFO}

Article history:

DOI:

10.30595/pssh.v1i.81

Submitted:

April 12, 2021

Accepted:

June 10, 2021

Published:

June 14, 2021

\section{Keywords:}

ABSTRACT

The google classroom application is one of the most preferred learning management system applications in the Purbalingga District education unit for learning during the Covid-19 outbreak because it is easy to use. The purpose of this research is to find out 1) student responses in easy access to the Google classroom application, 2) understanding of the material in learning using google classroom, 3) the effectiveness of using the google classroom application in online learning, 4) The use of google classroom in learning evaluation. This research method uses descriptive research methods using survey techniques. The research instruments used were questionnaires and online interviews which were given to 256 students of class IX in the odd semester of the 2020/2021 school year. The results showed that as many as $52.93 \%$ of students stated that they disagreed with the ease of accessing the google classroom application, 62.63\% of students agreed in understanding the learning material using google classroom, $60.42 \%$ of students agreed to the effectiveness of using the google classroom application, and $46.74 \%$ of students agreed to use the google classroom application in learning evaluation. It can be concluded that the use of the google classroom application in online learning during the Covid-19 outbreak was quite good and effective, it's just that it would be better if combined with other online platforms.
\end{abstract}

Google Classroom, Covid-19, Learning Management System
This work is licensed under a Creative Commons Attribution 4.0 International License.

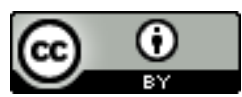

\author{
Corresponding Author: \\ Nur Said Manfaluti \\ Guru IPS SMP Negeri 2 Kalimanah, \\ Jalan Mayjend Sungkono, Kalimanah, Purbalingga, Jawa Tengah, Indonesia \\ Email: manfalutin@gmail.com
}

\section{PENDAHULUAN}

Corona Virus Disease 2019 (Covid-19) yang berasal dari Wuhan, Provinsi Hubei,Cina telah menyebar dengan cepat ke seluruh dunia. Pada tanggal 11 Maret, 2020 World HealthOrganization (WHO) bahkan telah mendeklarasikan kejadian ini sebagai pandemi global(Cucinotta dan Vanelli, 2020). Hal tersebut mengharuskan kita untuk melakukan karantinaCorona Virus Disease 2019 (Covid-19) yang berasal dari Wuhan, Provinsi Hubei,Cina telah menyebar dengan cepat ke seluruh dunia. Pada tanggal 11 Maret, 2020 World HealthOrganization (WHO) bahkan telah mendeklarasikan kejadian ini sebagai pandemi global [1]. Hal tersebut mengharuskan kita untuk melakukan karantina.

Pandemi Corona Virus Disease 2019 (Covid-19) di Indonesia mengharuskan sekolah menghentikan proses pembelajaran tatap muka. Sebagai gantinya, pembelajaran dilakukan dengan pembelajaran jarak jauh atau remote learning. Pembelajaran secara daring saat ini sesuai dengan Surat Edaran Menteri Pendidikan dan Kebudayaan Nomor 36962/MPK.A/HK/2020. Menteri Pendidikan dan Kebudayaan (Mendikbud) Nadiem Makarim juga berupaya membangun kerjasama dengan berbagai pihak yang fokus mengembangkan sistem pendidikan daring 
(dalam jaringan). Pada perkembangan Teknologi Informasi (TI) saat ini, kebutuhan akan suatu konsep dan mekanisme belajar mengajar berbasis TI menjadi tidak terelakkan lagi. Konsep yang kemudian terkenal dengan sebutan E-learning ini membawa pengaruh terjadinya proses transformasi pendidikan konvensional kedalam bentuk digital, baik secara isi (contents) dan sistemnya.

Pembelajaran secara online atau daring (dalam jaringan) dilakukan melalui berbagai aplikasi yang dapat menunjang proses pembelajaran mulai dari aplikasi tatap muka seperti zoom, google meet, dan platform media online lainnya seperti google classroom, whatsapp group, dan sebagainya.Aplikasi google classroom dipilih untuk membantu siswa dan guru sebagai pengajar melakukan pembelajaran secara online.Google classroom merupakan aplikasi berupa learningsystem management yang disediakan google dan bisa dihubungkan dengan email, sehinggamudah untuk diakses. Hampir $60 \%$ di satuan pendidikan SMP Kabupaten Purbalingga menggunakan google classroom dalam pembelajaran.Google classroom telah dirilis secara resmi pada Agustus tahun 2014. Google classroom merupakan aplikasi yang memungkinkan terciptanya ruang kelas secara online. Googleclassroom bisa menjadi sarana pendistribusian tugas, pengumpulan tugas, bahkan melakukanpenilaian terhadap tugas-tugas yang telah dikumpulkan. Selain itu, google classroom menyediakan fitur forum diskusi sehingga guru bisa membuka sebuah diskusi kelas yang bisa ditanggapi dan dikomentari seperti aktivitas berkomentar di facebook [2].

Google classroom memiliki beberapa fitur yang dapat digunakan dalam prosespembelajaran antara lain halaman utama yang dapat menampilkan tugas siswa, penyusunan kelas, penyimpanan data di google drive, dan dapat diakses melalui smartphone, selain itu juga dapat menampung semua jenis file, serta dapat menambahkan gambar profil. Selain itu terdapat pula fitur lain yang dapat digunakan oleh guru dalam mengembangkan materi pembelajaran yaitu reuse post, create question, create assignment, dan create topic. Google classroom bisa dikatakan salah satu media pembelajaran yang berbasis metode pembelajaran inkuiri karena google classroom dapat melibatkan kemampuan siswa secara maksimal dalam mencari,memahami, menyelidiki, menganalisis dan merumuskan hasil belajar (Gofur, 2018). Salah satu fitur yang akan sering digunakan oleh para guru dalam menggunakan google classroom adalah create assignment yang berfungsi untuk memberikan tugas kepada siswa, selain itu terdapat fitur create topic yang tidak kalah menarik dari fitur lainnya yaitu bisa digunakan untuk membuat topik materi pembelajaran yang akan dibahas di kelas virtual google classroom sehingga siswa bisa berpartisipasi aktif dalam pembelajaran baik di kelas biasa yang dilakukan secara tatap muka langsung maupun di kelas google classroom [3].

Penggunaan aplikasi google classroom sebagian besar digunakan di SMP Kabupaten Purbalingga dengan memadukan aplikasi lain seperti whatsapp group, zoom, dangoogle meet untuk menunjang proses pembelajaran. Penelitian ini bertujuan untuk mendeskripsikan tanggapan tentang kemudahan mengakses google classroom, kemampuan pemahaman materi menggunakan google classroom, efektifitas penggunaan google classroom dari segi kuota dan waktu serta penggunaan google classroom dalam evaluasi pembelajaran.

Google classroom bertujuan untuk memberikan kemudahan dalam membuat danmemberikan tugas kepada siswa yang bersifat paperless. Penugasan dalam googleclassroom berupa dokumen atau video dan diskusi. Selain itu juga bisa melakukan tes online menggunakan format google form dengan berbagai tipe soal. Untuk login ke google classroom, pengguna akun gmail hanya mencari dan klik menu google classroom yang sudah tersedia di akun gmail yang bersangkutan [4]. Beberapa tampilan google classroom penulis sajikan sebagai berikut:

a. Membuka halaman google classroom jika sudah memiliki email bisa langsung di link nya lalu create dan buat kelasnya, lalu ada kode kelas yang nantinya akan diberikan kepadasiswa untuk bergabung kemudian akan muncul tampilan seperti berikut

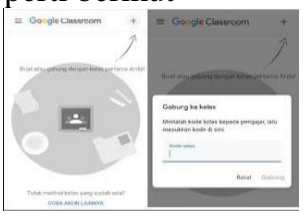

Gambar 1. Tampilan Google Classroom

b. Tampilan google classroom pada mata pelajaran IPS kelas IX

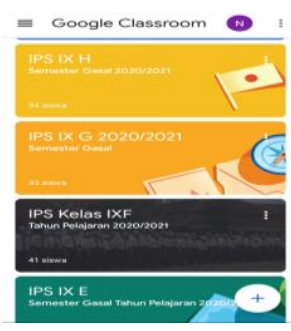

Gambar 2. Tampilan Google Classroom dengan tampilan mata pelajaran IPS Kelas IX 
Pengoptimalan fitur google classroom berdampak baik bagi pembelajaran saat ini, diantaranya adalah tidak terbatas oleh ruang dan waktu, materi pembelajaran yang dibutuhkan lebih mudah untuk diakses, serta mampu melatih keterampilan literasi data dan literasi teknologi. Google classroom dapat dijadikan sebagai media pembelajaran yang efisien, efektif, sertainteraktif untuk menunjang pembelajaran jarak jauh [4].

\section{METODE PENELITIAN}

Metode penelitian yang digunakan adalah penelitian deskriptif kualitatif dengan menggunakan teknik survey [5]. Instrumen penelitian yang digunakan adalah angket dan wawancara secara online dalam format google form. Sampel yang diambil adalah siswa kelas IX sejumlah 251. Angket tersebut diberikan kepada siswa yang sedang melakukan pembelajaran secara daring dalam mata pelajaran IPS. Angket yang diberikan terdiri dari 15 pernyataan dengan opsi jawaban sangat tidak setuju, tidak setuju, kurang setuju, setuju, dan sangat setuju. Adapun indikator dari angket tersebut terdiri dari empat indikator yaitu sebagai berikut; 1) respon siswa dalam kemudahan mengakses aplikasi google classroom, 2) pemahaman materi dalam pembelajaran dengan menggunakan google classroom, 3) keefektifan penggunaan aplikasi google classroom dalam pembelajaran daring, 4) Penggunaan google classroom dalam evaluasi pembelajaran IPS. Adapun pernyataan dari setiap indikator angket disajikan pada Tabel 1 di bawah ini.

\section{Tabel 1. Angket Umpan Balik Pembelajaran IPS Daring Berbasis Google Classroom}

\begin{tabular}{|c|c|c|}
\hline Indikator & $\begin{array}{l}\text { No. } \\
\text { Item }\end{array}$ & Pernyataan \\
\hline \multirow[t]{2}{*}{1} & 1 & $\begin{array}{l}\text { Saya dapat mengakses Google Classroom dengan mudah dan memahami cara } \\
\text { penggunaan aplikasi tersebut. }\end{array}$ \\
\hline & 2 & Tampilan Google Classroom sangat jelas dan mudah dipahami. \\
\hline \multirow{7}{*}{2} & 3 & Belajar IPS dengan menggunakan Google Classroom membuat saya lebih paham. \\
\hline & 4 & $\begin{array}{l}\text { Di masa wabah Covid-19 seperti ini, memiliki aplikasi Google Classroom sangat } \\
\text { membantu. }\end{array}$ \\
\hline & 5 & $\begin{array}{l}\text { Saya lebih dapat memahami diskusi kelompok melalui Google Classroom dibandingkan } \\
\text { diskusi melalui aplikasi lain. }\end{array}$ \\
\hline & 6 & $\begin{array}{l}\begin{array}{l}\text { Dengan aplikasi Google Classroom, memperoleh informasi, materi, maupun } \\
\text { pengumpulan tugas menjadi lebih mudah dan fleksibel. }\end{array} \\
\end{array}$ \\
\hline & 7 & $\begin{array}{l}\text { Pembelajaran dengan menggunakan Google Classroom lebih mudah dibandingkan } \\
\text { dengan aplikasi lainnya. }\end{array}$ \\
\hline & 8 & $\begin{array}{l}\text { Dengan Google Classroom, memudahkan saya untuk menyimpan dokumen materi } \\
\text { maupun tugas yang penting. }\end{array}$ \\
\hline & 9 & $\begin{array}{l}\text { Dengan menggunakan Google Classroom, memungkinkan siswa untuk memperoleh } \\
\text { umpan balik dengan lebih cepat. }\end{array}$ \\
\hline \multirow{4}{*}{3} & 10 & $\begin{array}{l}\text { Menggunakan Google Classroom lebih menghemat kuota dibandingkan dengan aplikasi } \\
\text { tatap muka. }\end{array}$ \\
\hline & 11 & $\begin{array}{l}\text { Dengan menggunakan Google Classroom memungkinkan saya untuk menyelesaikan } \\
\text { tugas dengan lebih cepat. }\end{array}$ \\
\hline & 12 & Guru aktif memberikan tanggapan, diskusi, atau tugas di aplikasi Google Classroom. \\
\hline & 13 & Dengan aplikasi Google Classroom dapat menghemat waktu. \\
\hline \multirow[b]{2}{*}{4} & 14 & $\begin{array}{l}\text { Jika ada evaluasi pembelajaran IPS secara daring, maka aplikasi Google Classroom } \\
\text { sangat cocok untuk digunakan. }\end{array}$ \\
\hline & 15 & $\begin{array}{l}\text { Jika ada evaluasi pembelajaran IPS secara daring, maka sebaiknya mengkombinasikan } \\
\text { Google Classroom dengan aplikasi daring lainnya seperti google form. }\end{array}$ \\
\hline
\end{tabular}

\section{HASIL PENELITIAN}

Data yang telah diperoleh kemudian dianalisis untuk selanjutnya dideskripsikan. Adapun hasil dari analisis tersebut adalah sebagai berikut:

\section{Penggunaan Google Classroom oleh Siswa Kelas IX dalam Pembelajaran IPS Daring}

Google classroom mampu menyederhanakan komunikasi antara guru dansiswa serta mampu memberikan kemudahan dalam mendistribusikan dan menilai tugas. Selain itu, siswa dapat mengumpulakn tugasnya dalam tenggat waktu tertentu yang selanjutnya akan diperiksa secara langsung oleh guru [6]. Kelas elektronik ini juga dapat membuat folder penyimpanan untuk setiap tugas dan setiap siswa sehingga semuanya tetap teratur dan rapi. Siswa dapat melacak setiap tugas yang hampir mendekati batas waktu pengumpulan di halaman tugas, dan mulai mengerjakannya cukup dengan satu klik saja. Selain itu, guru dapat melihat dengan cepat siapa saja yang belum menyelesaikan tugas tersebut, serta memberikan masukan dan nilai secara langsung. Google classroom tidak 
mengandung iklan dan tidak pernah menggunakan data siswa untuk kebutuhan iklan dan lain sebagainya sehingga aman untuk digunakan terlebih lagi google classroom ini bersifat gratis [7]. Google classroom gratis ini disediakan untuk sekolah, lembaga nonprofit, dan perorangan [8].

Berdasarkan deskripsi di atas, terdapat banyak kemudahan yang disediakan oleh google classroom dalam menunjang pembelajaran jarak jauh sehingga tentunya aplikasi inidigunakan oleh banyak orang. Namun berdasarkan hasil survey dalam skala pembelajaran Daring IPS pada siswa kelas IX menunjukkan bahwa sebanyak $51,14 \%$ siswa menyatakan setuju dan 39,09\% menyatakan sangat setuju. Hal tersebut dapat diartikan bahwa kebanyakan siswa baru pertama kali menggunakan aplikasi google classroom dalam pembelajaran daring yang diterapkan saat ini. Data tersebut dapat dilihat pada Gambar 3 yang disajikan di bawah ini.

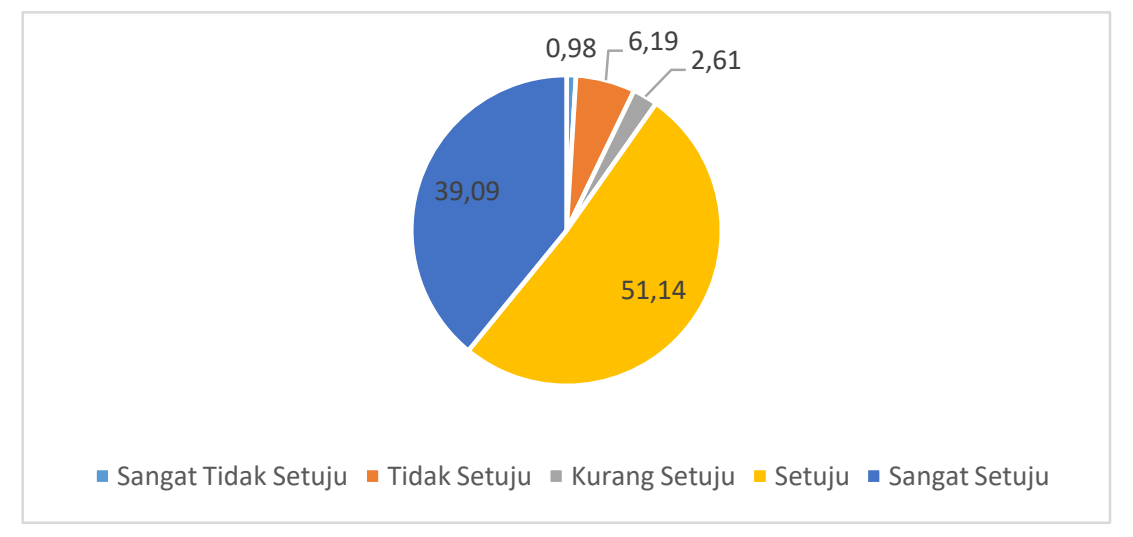

Gambar 3. Diagram Penggunaan Google Classroom

Pada Gambar 3 terlihat bahwa jumlah siswa yang telah menggunakan aplikasi google classroom sebelumnya hanya sebesar $0,98 \%$ siswa yang menyatakan sangattidak setuju, 6,19\% menyatakan tidak setuju, dan 2,61\% menyatakan kurang setuju. Hal ini menunjukkan bahwa penggunaan aplikasi google classroom dalam proses pemebelajaran masih kurang sedangkan terdapat beberapa penelitian yang menyebutkan bahwa penggunaan aplikasi ini mampu memberikan pengaruh yang positif terhadap pembelajaran. Adapun penelitian yang telah dilakukan sebelumnya dengan judul "Pengaruh Media Pembelajaran Google Classroom dalam Pembelajaran IPS terhadap Motivasi Belajar Siswa" menunjukkan bahwa terdapat pengaruh signifikan dalam motivasi belajar siswa setelah diterapkan pembelajaran google classroom. Hal ini ditunjukkan dengan nilai thitung $=43,116$ dengan nilai $p=0,000$ $<\alpha=0,05$. Selain itu, nilai skor rata-rata hasil belajar siswa dan persentase nilai respon siswa masing-masing sebesar 78,31 yang berada pada kategori tinggi dan 83,72\% yang berada pada kategori sangat baik [9].

Hasil penelitian lainnya dengan judul "Pengaruh E-Learning dengan GoogleClassroom terhadap Hasil dan Motivasi Belajar IPA Siswa" menunjukkan bahwa rerataN-Gain kelas eksperimen sebesar 0,612 dan rerata pada kelas kontrol adalah 0,486 sedangkan rerata N-Gain motivasi belajar pada kelas eksperimen sebesar 0,39 dan pada kelas kontrol hanya 0,27. Terdapat perbedaan yang signifikan antara kelas eksperimen dan kelas control dari uji $t$ yang dilakukan. Berdasarkan data ini maka dapat disimpulkan bahwa terdapat pengaruh e-learning dengan google clasroom terhadap hasil belajar dan motivasi belajar siswa [8].

Mengingat pengaruh positif yang diberikan dari penggunaan aplikasi tersebut, maka google classroom baik digunakan dalam pembelajaran daring pada masa wabah covid-19saat ini. Untuk mengetahui hal tersebut, dilakukanlah survey dengan menggunakan angket kepada siswa yang terdiri dari empat indikator yaitu respon siswa dalam kemudahan mengakses aplikasi google classroom, pemahaman materi dalam pembelajaran dengan menggunakan google classroom, keefektifan penggunaan aplikasi google classroom, penggunaan aplikasi google classroom dalam evaluasi pembelajaran IPS. Adapun hasil survey tersebut dapat dilihat pada Gambar 4 yang disajikan di bawah ini. 


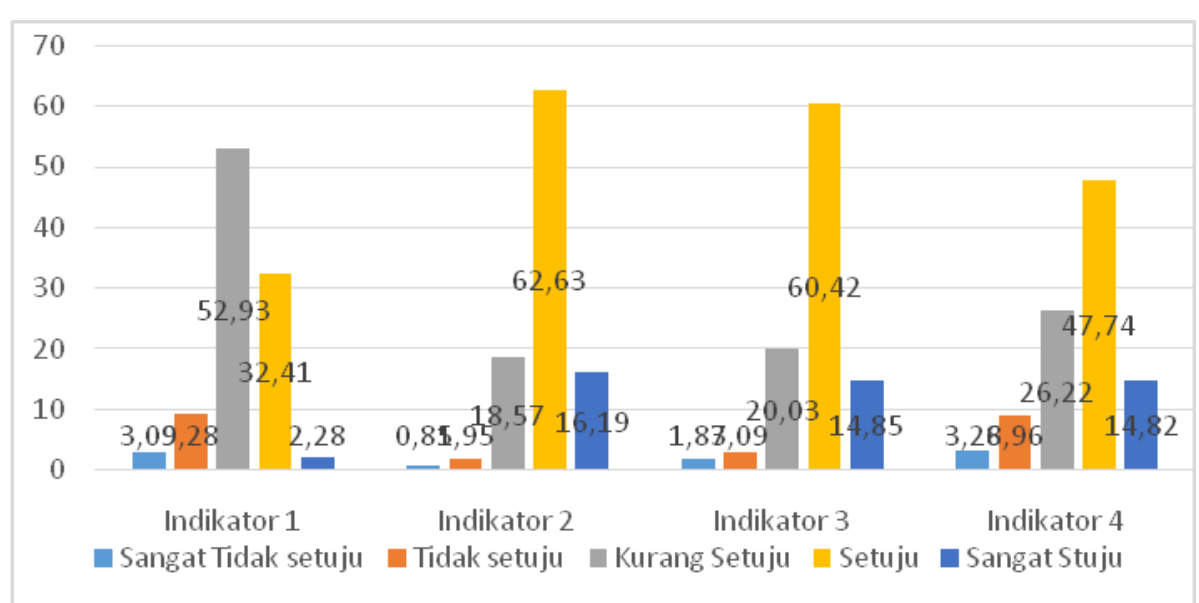

Keterangan :

Gambar 4. Grafik Pembelajaran Daring Berbasis Google Classroom

Indikator 1: Respon siswa dalam kemudahan mengakses aplikasi google classroom

Indikator 2: Pemahaman materi dalam pembelajaran dengan menggunakan google classroom

Indikator 3 : Keefektifan penggunaan aplikasi google classroom

Indikator 4 : Penggunaan aplikasi google classroom dalam evaluasi pembelajaran IPS

Berdasarkan Gambar 4, dapat diketahui bahwa untuk indikator pertama sebanyak 52,93\% siswa menyatakan kurang setuju dalam kemudahan mengakses aplikasi googleclassroom. Indikator kedua sebanyak 62,63\% siswa menyatakan setuju dalampemahaman materi pembelajaran dengan menggunakan google classroom. Indikator ketiga sebanyak $60,42 \%$ siswa menyatakan setuju dalam keefektifan penggunaan aplikasi google classroom. Indikator keempat sebanyak $46,74 \%$ siswa menyatakan setujudalam penggunaan aplikasi google classroom dalam evaluasi pembelajaran IPS.

Nilai terendah berdasarkan Gambar 3 diperoleh sebanyak 46,74\% pada indikator penggunaan aplikasi google classroom dalam evaluasi pembelajaran IPS. Hal ini terjadi karena pembelajaran IPS harus dilakukan secara kolaboratif antara tatap muka dengan daring yaitu menggunakan google classroom sehingga pembelajaran menjadi lebih bermakna karena materi pembelajaran yang disediakan dirancang sedemikian rupa sehingga siswa akan lebih mudah memahaminya.

Untuk indikator pemahaman materi dalam pembelajaran dengan menggunakan google classroom memperoleh nilai tertinggi yaitu sebesar 62,63\%. Hal ini sesuai denganhasil penelitian denga judul "Persepsi Peserta Didik terhadap Metode Blended Learning dengan Google Classroom" yang menunjukkan hasil bahwa melalui Google Classroom membuat proses pembelajaran menjadi menarik, efektif, menumbuhkan motivasi, menumbuhkan sikap belajar mandiri, aktif, dan kreatif. Selain itu, metode ini juga dapat meningkatkan pemahaman dan hasil belajar peserta didik [10].

Nilai yang diperoleh untuk indikator kemudahan dalam mengakses googleclassroom sebesar 52,93\% siswa menyatakan kurang setuju, karena berdasarkan salahsatu saran yang masuk dari siswa menyebutkan bahwa secara keseluruhan pembelajaran dengan menggunakan google classroom memang menawarkan fitur yang lebih bervariatif hanya saja notifikasi google classroom tidak terlalu fleksibel seperti aplikasi lainnya dan membutuhkan jaringan internet yang lebih kuat. Selain itu juga harus melakukan scroll ulang.

Berbeda dengan hasil penelitian tentang efektifitas penggunaan LearningManagement System berbasis google classroom dalam pembelajaran dan kelayakan

Learning Management System berbasis google classroom sebagai media pembelajaranmenunjukkan bahwa pembelajaran menggunakan google classroom sangat efektif, karena banyak mendapatkan respon positif dari siswa, guru, dan pengguna lainnya. Kelayakan google classroom sebagai media pembelajaran menunjukan rata-rata hasil validasi yang sangat baik, sehingga dapat dikatakan layak sebagai media pembelajaran.

Dari hasil pembelajaran IPS daring berbasis google classroom pada masa wabah covid-19 dapat disimpulkan bahwa penggunaan aplikasigoogle classroom dalam pembelajaran daring pada masa wabah covid-19 sudah cukup baik danefektif, hanya saja akan lebih baik jika dipadukan dengan platform online lainnya.

\section{KESIMPULAN}

Pelaksanaa pembelajaran daring di kelas IX SMP Negeri 2 Kalimanah pada masa wabah Covid-19 dapat memberi dampak terciptanya kemandirian belajar siswa untuk belajar dengan memanfaatkan jaringan internet. Maka pelaksanaa pembelajaran daring di masa datang akan tetap dilaksanakan untuk materi-materi yang bersifat hafalan atau dengan tingkat kesukaran yang tidak terlalu tinggi. Untuk materi sulit dan memerlukan banyak latihan soal, jika 
situasi sudah memungkinkan adanya pembelajaran di kelas lebih baik dilaksanakan secara tatap muka. Dalam pelaksanaan pembelajaran dimasa datang meskipun pembelajarn sudah dilaksanakan di kelas, aplikasi googleclassrrom tetap digunakan untuk mengelola tugas dan pengadministrasian nilai tugas.

\section{DAFTAR PUSTAKA}

[1] Cucinotta, D., dan Vanelli, M. 2020. WHO Declares Covid-19 a Pandemic: Acta Biomed, 91(1), 157-160.

[2] Kusuma, A., dan Astuti, W. 2019. Analisis Penerapan Media Pembelajaran Bahasa Arab Berbasis Aplikasi Google Classroom: Jurnal Lahjah Arabiyah, 67-89.

[3] Hapsari, S., dan Pamungkas, H. 2019. Pemanfaatan Google Classroom sebagai Media Pembelajaran Online di Universitas Dian Nuswantoro. Wacana, 18(2), 225-233.

[4] Maolani A.R. dan Cahyana U. (2016). Metodologi Penelitian Pendidikan.Rajagrafindo Persada: Jakarta

[5] Hakim, Abdul Barir. 2016. Efektivitas Penggunaan E-Learning Moodle, Google Classroom dan Edmodo. Jurnal: I-Statement. Vol. 02 No.1.

[6] Al-Maroof, R., dan Al-Emran, M.2018. Student's Acceptance of Google Classroom : AnExploratory Study using PLS-SEM Approach. I-JET, 13(6), 112-123.

[7] Putri, G., dan Dewi, Y. 2019. Pengaruh Model Pembelajaran Jarak Jauh Berbasis Google Classroom: AlFikrah, 2(1), 60-79.

[8] Rikizaputra, dan Sulastri, H. 2020. Pengaruh E-Learning dengan Google Classroom terhadap Hasil dan Motivasi Belajar Biologi Siswa. Lectura: Jurnal Pendidikan, 11(1), 106-118.

[9] Nirfayanti dan Nurbaeti. 2019. Pengaruh Media Pembelajaran Google Classroom dalam Pembelajaran Analisis Real terhadap Motivasi Belajar Mahasiswa: Jurnal Penelitian Matematika dan Pendidikan Matematika, 2(1), 50-59.

[10] Hikmatiar, A., Sulisworo, D., dan Wahyuni, M. 2020. Pemanfaatan Learning Management System Berbasis Google Classroom dalam Pembelajaran: Jurnal Pendidikan Fisika, 8(1), 1-9. 